\title{
Lingual Artery
}

National Cancer Institute

\section{Source}

National Cancer Institute. Lingual Artery. NCI Thesaurus. Code C52961.

An artery arising from the external carotid artery between the thyroid and facial arteries

that runs under the tongue and becomes the deep lingual or ranine artery. 